\title{
14. THE VIOLIN IN L'HISTOIRE DU SOLDAT - A METAPHOR OF THE SOUL
}

\author{
Oana Iuliana Vișenescu ${ }^{123}$
}

\begin{abstract}
From 1909, Stravinsky manifested a keen interest in composing theatre music, as proves the many and various dedicated scores. Almost all of his large works, from the ballet The Firebird (1909-10) to the one-act opera buffa Mavra (1921-22), are written for the stage. Stravinsky thus worked most of the time with scenic presentations, with questions on movement, dance, gestures or scenic tableaus. He develops a particular theatrical instinct: his works have a good scenic orientation, and the correlation with modernism and the new currents in theatre aesthetics is more than obvious. Critics have already analysed and discussed the parallels with such contemporary theatrical concepts as by Bertold Brecht (1898-1956) or Vsevolod Meyerhold (1874-1940). After three great ballets, whose new conception by Stravinsky and Sergei Diaghilev (1872-1929) brought about a fundamental revolution in dance aesthetics, the composer crystallises his notion of incidental music. The aesthetics of L'Histoire du soldat, a work "to be read, played and danced", is opposed to that of Richard Wagner (1813-83) and his Gesamtkunstwerk (a work blending various arts, a total work of art): a new artistic idea, frozen in gesture and movement, compressed, finding its concentrated expression. Stravinsky establishes a brilliant draft of the issues of Opera, to which he would from now on dedicate himself. Stravinsky's theatre music reveals a tendency to introduce new concepts in the works written between Sacre du printemps and Pulcinella. A quick look at his stage works before and after L'histoire is necessary in order to fit it in his artistic view.
\end{abstract}

Key words: $a$ work blending various arts, a total work of art

\section{Introduction}

Les Noces (1914-1923)

In 1912, while working on Le Sacre, Stravinsky comes up with the idea of a ballet-cantata. The subject of this Russian dance in four tableaus after a collection of old traditional songs is a local peasant wedding. The composer aimed for a regular dramatization and for the avoidance of any individualization of characters, wanting to present the subject by means of folk quotations and not by literary verses. The tableaus are ritualist. The assortment of typical, melisma-like turns, presented without descriptive functions, without the backbone of the dramatic expression and without a context of a literary meaning, is Stravinsky's way of processing the melismatic musical elements of an invented, not imitated, folklore. ${ }^{124}$ Constituent part of this principle of the intended arrangement is thus the separation of the singers (four soloists and chorus) from the actors (dancers). The separation is on a functional level too, because the solo parts don't represent the characters necessary for the unfolding of the action. ${ }^{125}$ In Stravinsky's

\footnotetext{
${ }^{123}$ Lecturer PhD., National University of Music from Bucharest, Romania, email: oanavisenescu@yahoo.com 124 "It was not my intention to reproduce the ritual of peasant weddings, and I paid little heed to ethnographical considerations. My idea was to compose a sort of scenic ceremony, using as I liked those ritualistic elements so abundantly provided by village customs which had been established for centuries in the celebration of Russian marriages. I took my inspiration from those customs, but reserved to myself the right to use them with absolute freedom". Ramuz, Charles Ferdinand, Erinnerungen an Igor Stravinsky, Frankfurt a. Main, 1974

125 "Individual roles do not exist in Les Noces, but only solo voices that impersonate now one type of character and now another". Ramuz, Charles Ferdinand, Erinnerungen an Igor Stravinsky, Frankfurt a. Main, 1974
} 
conception, the alienation principle in Les Noces (premiered in 1923) should be underlined radically also by the scenic realization, as it had meanwhile happened with L'histoire, first performed on September 28, 1918 at the Municipal Theatre in Lausanne. ${ }^{126}$ During the years he lived in Morges, on the shores of the Geneva Lake, Stravinsky showed a tendency to reduce instrumentation. Having originally written it for large orchestra, the composer reduces and arranges Les Noces first for keyboard instruments, cimbalom and winds and then, strangely, for an unusual four piano and percussion ensemble.

\section{Renard (1915-1916)}

The libretto of this burlesque for the stage based on an old Russian animal story is taken from the folk tale collection by ethnographer Alexander Afanasyev. This work written for four pantomimes, singers and chamber ensemble was a step forward to L'histoire. Renard too is overtly opposed to the illusionist musical theatre. ${ }^{127}$ As in Les Noces, roles are not identified with singers, and Stravinsky imposes a surprising scenic disposition. ${ }^{128}$ The separation of the actors' and singers' thought and action as well as the on-stage instrumentalists would from now on be a trademark of Stravinsky's musical-dramaturgic repertoire. He places the sound of a gusle, a model of balalaika, against a musical background in march character. Unlike in Les Noces and like in L'historie, in Renard we find such elements as satire, narration and play, traditional dance, fair shows music, concretised in a wind, percussion and plucked strings ensemble.

Pulcinella (1919-1920)

The voice ballet Pulcinella is selected from the theatrical subjects in commedia dell'arte and is written for two wind ensembles and two strings groups, composed of a concertino and a ripieno-quintet. This ballet is the pinnacle of the technique of processing traditional dance with modern elements. Four decades after its completion, Stravinsky said: "Pulcinella was my discovery of the past, the epiphany through which the whole of my late work became possible. It was a backward look, of course... but it was a look in the mirror, too". ${ }^{129}$

\section{Discussions}

\section{The origins of $L$ 'histoire}

The six years of Swiss exile (1914-20) forced the greatly venerated composer to isolation and financial constraint, all of which played a role also in the change

\footnotetext{
126 "I wished to place the orchestra on the stage itself, letting the actors move on the space remaining free. The fact that the artists in the scene would uniformly wear costumes of a Russian character while the musicians would be in evening dress not only did not embarrass me, but, on the contrary, was perfectly in keeping with my idea of a divertissement of the masquerade type". Ramuz, Charles Ferdinand, Erinnerungen an Igor Stravinsky, Frankfurt a. Main, 1974

127 "I planned the staging myself, always keeping in mind that Renard is by no means to be mistaken for an opera. The protagonists must be acrobat dancers, and the singers are not allowed to identify with their roles; the relation between sung parts and the roles on stage is the same as in Les Noces; indeed, the protagonists should again be on stage all at once, the singers in the middle of the instrumentalists". Ramuz, Charles Ferdinand, Erinnerungen an Igor Stravinsky, Frankfurt a. Main, 1974

128 "Renard must be performed by clowns, dancers and acrobats, preferably on a podium, with the orchestra in the background. (...) The actors don't speak. The singers (two tenors, two basses) are in the orchestra". Ramuz, Charles Ferdinand, Erinnerungen an Igor Stravinsky, Frankfurt a. Main, 1974

${ }^{129} \mathrm{https} / / /$ www.latimes.com/archives/la-xpm-1990-09-30-ca-2098story.html\#: :text=\%E2\%80\%9CPulcinella'\%20was\%20my\%20discovery\%20of,in\%20the\%20mirror\%2C\%20too $\% \mathrm{E} 2 \% 80 \% 9 \mathrm{D}$
} 
that took place in the oeuvre of the master. In the spring of 1914, Stravinsky meets Ernest Ansermet (1883-1969), conductor in Montreux, who in the following winter invites the Stravinskys to his home in Clarens. In the spring of 1915, the composer moves with his family in Morges, a small town on the shores of the Geneva Lake, about $15 \mathrm{~km}$ west of Lausanne. Through the Ansermets Stravinsky is introduced, in the fall of 1915, to Charles Ferdinand Ramuz (1878-1947), a local poet, whom he quickly befriends and whom he invites to collaborate on Renard. This partnership on the translation of the text from Russian to French, with the problems of the respective languages' spoken rhythm, led to an intensive artistic exchange between storyteller and composer. The friendly cooperation on this as well as on other projects (Les Noces) encouraged them to not only translate Stravinsky's Russian lied cycle into French, but also to bring the composer closer to the unusual conception of L'histoire.

Born in Pully, near Lausanne, in 1878, Charles Ferdinand Ramuz studied classical philology in Lausanne and Paris and established himself as a private teacher before turning freelance writer. As poet and novelist, from wood carver and accomplished orator, Ramuz became the voice of the traditional, peasant tales of the Vaud canton. The mutual understanding between Ramuz and Stravinsky was based on the aesthetics of the view according to which man must be both savage and civilized, as Ramuz recalls. ${ }^{130}$ From several of his writings we can see that his poetics shared the same contents with Stravinsky's technic-aesthetic intentions. ${ }^{131}$

\section{The libretto of L'Histoire}

Alexander Afanasyev's folklore anthology, with which Stravinsky had been long acquainted, had already inspired the composer: setting parts of it to music, he later arranged the melodies for The Firebird and Petrushka. Stravinsky would now base L'Histoire on the same anthology. Stravinsky was interested in those soldiers' stories recounting the inhuman military recruitment practices during the Russo-Turkish war under Nicholas I of Russia. In these stories, the soldier must confront the devil, sometimes defeating it, sometimes losing his soul. Ramuz, to whom the composer entrusted texts in Russian to translate into French, is deeply impressed by this set of stories about the soldier and the devil, so that he sets to work right away. Ramuz, who was a novelist and not a playwright, leaves no doubt as to the character of the story, which he wanted as one epic. World War 1 and the Russian Revolution helped create the atmosphere necessary for the birth of L'Histoire.

\section{Results}

\subsection{The scenic design and the orchestral arrangement The scenic design}

Ramuz conceived a story to be read, played and danced. A visible, on-stage narrator presents and comments L'Histoire. The soldier and the devil must be

\footnotetext{
${ }^{130}$ Ramuz, Charles Ferdinand, Erinnerungen an Igor Stravinsky, 1929

131“The inventiveness must be not in the work's theme, but in the way that work is organised and presented. It consists of sound, choice, image, it consists of the rhythmic parading of the movements, and of nothing else". Ramuz, Charles Ferdinand, Erinnerungen an Igor Stravinsky, Frankfurt a. Main, 1974
} 
played by actors able to deliver the story both by dialogue and pantomime, while the role of the princess and the devil's dancing role are performed by dancers (female and male).

The separation of such elements as acting, story, dance, and music is realized by the scenic disposition: the narrator is positioned on one side of the stage, the instrumentalists on another side, and in the middle of the stage there is an elevated platform destined the actors. Each element has its clearly defined function: L'Histoire is narrated, some episodes are acted, and music will play during singular episodes (march, dance, chorale). The decision to write the score for a small instrumental ensemble, as the composer later wrote in Chronicle of My Life, was for him particularly attractive. ${ }^{132}$ The authors' proposal to decorate the fabric wall panels with illustrated sheets of paper speaks about the idea of theatre shows put on at fairs. The strained circumstances, the shortages caused by the war which had scarred Switzerland too, especially as concerns artistic productions, determined Ramuz and Stravinsky to conceive their show with great economy of means, making it easy to travel and to host. In various forms, Stravinsky had revealed his interest in funfair theatrical performances in Petrushka and especially in Les Noces and Renard, and would later express it again in the commedia dell'arte-inspired Pulcinella.

As a reply to European opera as dominated by Wagnerian musical dramas on the one hand and by Italian Verismo dramaturgy on the other hand, Ramuz and Stravinsky aim to create an anti-opera, a grotesque artistic expression, manifest particularly in the orchestral scenic disposition and in the separation of the elements (acting, tableau, dance, gestures, music) and being, on the whole, the opposite of the Gesamtkunstwerk, which it decomposes.

\section{The arrangement for septet}

The only instrumental arrangement of L'Histoire is a logical consequence not only with Stravinsky, but also with Erik Satie (1866-1925) or Jean Cocteau (18891963), who follow the Russian composer in such radical composing techniques as simplifying the musical means and creating a transparent sound.

Jean Cocteau, with whom Stravinsky had an extraordinary artistic friendship after the premiere of Le Sacre, wrote in the manifesto of the new classicism Le Coq et l'Arlequin about the clear outlines, about a precise architecture and a "minimal aesthetics". Cocteau, a fierce and vocal anti-Wagnerian, had for that matter developed the first program of Neo-Classicism. Stravinsky, though, will neither accept nor too willingly borrow this novel concept; he read a lot of Japanese literature and he was influenced by the extraordinary conception of Japanese artwork as well as by how Schoenberg (1874-1951) employed

\footnotetext{
132 “...the interest afforded to the spectator by being able to see these instrumentalists each playing his own part in the ensemble. I have always had a horror of listening to music with my eyes shut, with nothing for them to do. The sight of the gestures and movements of the various parts of the body producing the music is fundamentally necessary if it is to be grasped in all its fullness. (...) [T]hose who maintain that they only enjoy music to the full with their eyes shut do not hear better than when they have them open, but the absence of visual distractions enables them to abandon themselves to the reveries induced by the lullaby of its sounds, and that is really what they prefer to the music itself. These ideas induced me to have my little orchestra well in evidence when planning L'Histoire du soldat. It was to be on one side of the stage, and a small dais for the reader on the other". Burde, Wolfgang. Stravinsky. Leben, Werke, Documente. Schott/Piper. Mainz und München, 1982
} 
counterpoint and by the polyphonic structure of Pierrot lunaire (dialogue with R. Craft, 1961).

In this arrangement of L'Histoire, Stravinsky operated a massive reduction of the orchestral apparatus, especially as compared to Richard Wagner's, and this he stated repeatedly. ${ }^{133}$ The composer would in fact later show that L'Histoire is the last work based on the Russian school of composition. This reduction, of a large orchestra to a small ensemble, is however accomplished by a concrete selection of instruments, which needs to be explained. Here is the funfair conception of the music, with the specific instrumentation:

Violin - chosen not only because it is a melodic instrument that covers the higher register of string instruments, but also because it represents the soldier's soul. The violin is assigned a virtuoso role and is also entrusted with the elements of folk music.

Double bass - chosen both because of its lower register and for its qualities as an accompanying instrument (especially in pizzicatto), used in the folk- and jazz-inspired sections.

Clarinet - chosen for its extraordinary wide compass, used in the wind ensemble and in the dance ensemble.

Bassoon - with a caricatural tone colour in the higher register in particular. Captivated by its sonic dramatism, Stravinsky often employed this instrument in the higher and extreme high register (the opening of Sacre du printemps). He also frequently used it to depict pastoral moments requiring aerial sonorities, as for instance in its dialogue with the clarinet, in the first movement or in scene 2.

Cornet - not only an instrument present in fair music, but also used as a musical signal instrument and for dance music.

Trombone - multiple sound possibilities, a wide colour palette, as well as a wide register, like the clarinet and bassoon. Among its specific techniques are the glissandi or the muted sounds.

Percussion - it had to be diverse, but played by a single instrumentalist. Maybe this is why there are no large instruments, instead drums are present in several sizes, because just as the violin symbolizes the soldier's soul, so the drums represent the devilish spirit, being in fact the devil's drums.

An important factor in this line-up was for Stravinsky his experience in jazz music. ${ }^{134} \mathrm{~A}$ jazz band is made up of cornet (later replaced by the trumpet due to the latter's clearer, sharper sound), trombone, double bass, and percussion, in addition to which the composer, not only for register- but for sound-related reasons too uses the clarinet instead of the saxophone. ${ }^{135}$ What Stravinsky writes in An Autobiography about the sound material of his Ragtime for 11 instruments

\footnotetext{
133 "So there was nothing for it but to decide on a group of instruments, a selection which would include the most representative types, in treble and bass, of the instrumental families: for the strings, the violin and the double bass; for the wood, the clarinet, because it has the biggest compass, and the bassoon; for the brass, trumpet and trombone, and, finally, the percussion manipulated by only one musician". Craft, Robert, Stravinsky, Igor. Memories and Commentaries. London, 1960

134 "It is indicative of the passion I felt at that time for jazz, which burst into life so suddenly when the war ended. At my request, a whole pile of this music was sent to me, enchanting me by its truly popular appeal, its freshness, and the novel rhythm which so distinctly revealed its Negro origin. These impressions suggested the idea of creating a composite portrait of this, new dance music...". Hunkemöller, Jürgen. Igor Strawinsky's Jazz-Portrait. Archiv für Musikwissenschaft, 1972

135 Stravinsky thought that the saxophone was less penetrating
} 
(1918) also applies to the dance in L'Histoire. The jazz character is present not only in "Ragtime", but in "March" and "Tango" too.

\subsection{L'Histoire du soldat, suite for clarinet, violin and piano}

We can say that Stravinsky created a minimalist aesthetics in music too. In this conceptual line, he arranged the music for clarinet, violin and piano, believing these instruments to be ideal for preserving the character of the initial score. If here the violin is understood to be the soldier's soul, with an extraordinary melodic role, the clarinet proved it can successfully take over the sound material played in the octet by the bassoon, trombone and trumpet. The author writes for both the clarinets in B-flat and in A, employing them according to the particular musical character: in A for a softer, warmer sound in the melismas, and in B-flat for the dance music, requiring an incisive, brighter sound, as well as in the bravura passages.

Rhythmic incisiveness is the essential feature of Stravinsky's music. It is joined by the economy of the material employed and by the composer's extraordinary capacity to create a living, complex universe from just a few sounds. It is all just a natural consequence of the sap of the archaic Russian folklore, which means modalism and polymodality, ostinato, the simplicity of melodic elements, rhythmic asymmetry, a minimal but efficient variational technique. All this is organically assimilated in Stravinsky's style, landmark in the entire musical output of the $20^{\text {th }}$ century.

Stravinsky creates sonic blocks in which the material is based on the ostinato principle and which are then juxtaposed asymmetrically. The forms are based on affirmation and reiteration. The repetitions are asymmetrized by metric and rhythmic variation, by the introduction of accents and rests. Bar lines have no jurisdiction over Stravinsky's rhythmic complexity. The quality of his ostinatos resides in the combination of the static motion with the one frenzied. The obsessive repetition and the reduction to the minimum of the material does create the feeling of a closed circle, just as inside of this circle we discover the continuous variation of dimensions, of placement in time of motifs and their accents, the play of juxtapositions and superimpositions, the asymmetrization creating a diffuse but permanent tension. The interest is maintained at a high pitch even inside the ostinatos, by means of changes, interruptions, asymmetrical thematic insertions.

We owe the first in-depth analysis of Stravinsky's asymmetrization technique to Olivier Messiaen (1908-92), who called Stravinskyian cells rhythmic characters which evolve, dilate, and contract like living organisms. Pierre Boulez (19252016) proves that Sacre du printemps is the first art music work based on an essentially rhythmic language after those by Guillaume de Machault (1300-77) and Guillaume Dufay (1400-74). ${ }^{136}$ All these elements typical of his three masterpieces, The Firebird, Sacre du printemps, and Petrushka, are present in L'Histoire. As a novel element, Stravinsky moulds his material into characteristic dance rhythms, their effects amplified by the cultural and implicitly semantic connotations. The waltz, tango, march or ragtime from L'Histoire are not simple

\footnotetext{
${ }^{136}$ Pierre Boulez - Points de repère, Jean Jacques Nattiez ed. C. Bourgois, 1981
} 
loans, they undergo the play of distorting mirrors with the cold, typically Stravinskian humour: time signature changes, asymmetrical insertions, accents on the wrong beat or part of the beat. The form intensifies the tendency towards clear, static, ostinato-based blocks, already manifested in Sacre du printemps, opposing in alternative or repetitive cycles, which acquire vitality and a sense of movement by the dimension changes, by superimpositions, shifts and permutations.

In Marche $d u$ soldat, the violin has a predominantly rhythmic role, the composer mandating certain bow strokes: jeté, saltando, staccato. The incipient motif is marked jeté, demanding from the player a thrown spiccato controlled by the forearm; this motif alternates with a succession of very short sixteenth notes, separated by rests, marked très court and $\mathbf{V}$, up bow.

In Le violon $d u$ soldat, the violin has a solo role, the composer allowing the performer to display their virtuosity both in the right hand, which juggles with various bow strokes (spiccato, staccato, saltato) and in the right hand, where the fingers have a more difficult disposition (moving the first finger from the $\mathrm{G}$ string to the D string, in a fast tempo, a passage which repeats obsessively several times). The violin has a mini-cadenza in double stops, featuring complex technical elements: a succession of sixths, in third and fourth positions, in legato, a glissando on double stops. All thematic contours in Sacre du printemps are based on pre-pentatonic scales, with the intervals of the third and the fourth predominating. The same happens in L'Histoire, especially in the first two movements.

As in the first movement, the ostinato is again predominant in Le violon $d u$ soldat. If in the first movement the $G-D-E$ ostinato in the bass voice imposes the intervallic relation of (descending) fourth and third in relation to the gravitational sound $\mathrm{G}$, as well as three of the four open strings, G, D, and E, in the second movement the sounds G, D and A are open strings too, gravitate again around $G$ and form a trichord generated by the perfect fourth and its inversion, the perfect fifth. The diatonicism and the focus on a limited number of sounds is the material with which Stravinsky builds a living, energetic music.

In the third movement named Petit Concert, the violin's musical discourse is based on a series of 3- and 4-sound chords, in $f_{s}$ sempre non arpeggiato, which means that these chords are to be played in triple or quadruple stopping, martellato, short, almost wildly. As in the entire suite, accents are important, and they are sometimes placed on the first and the fourth eighth note, sometimes on the first and the third eighth note in 5/8. The third movement is a culmination of the cycle composed of the first three pieces: the lively tempo, the maximal tension and the recapitulation of the motifs of the first two movements are the main characteristics of this concerto in atypical rondo form.

The novel element of the work resides in the introduction of the three characteristic dance rhythms, tango, waltz, and ragtime, in this concert version work that belongs to the classical genre. The motivations of the scenario lead to moments when refined irony and humour are a perfect match for Stravinsky's strange harmonies and his predilection for asymmetry, bi-modalism and continuous variation.

The last movement with the title The Devil's dance, is the conclusion of the 
entire cycle. The devil's dance once more reveals Stravinsky's art in building with just a few gestures and sounds a fresh, living, interesting sound-universe, at the same time simple and complex, unitary and diverse. The rhythmic incisiveness highlights the simple melodies based on a couple of cells recurrent throughout the work.

\section{Conclusions}

L'Histoire du soldat is Stravinsky's way of describing on the one hand the difficult, inhuman conditions of the life of those enrolled and sent to death by the leaders of the nations which fought in World War 1, and on the other hand the human condition in general, life, death, with all that they represent, and especially with what happens in between. Metaphorically, Stravinsky captures the essence of the multitude of human emotions: the soldier drifts between hopes, dreams, deceptions, joy and pain. Aware of an ephemeral physical existence full of dominant temptations, his capacity to love taken away, he falls, chained by his own weaknesses. A parabolic image results, of the man erring on paths far away from the truth, charmed the glimmer of false values. The composer interprets the Faustian myth in which the soldier's violin, brought to life by the grace of music, symbolizes his soul, sold but retrieved through intelligence and courage.

As Stravinsky himself said, his music must be told, played and danced. Extraordinarily suggestive, it takes every form of expression so that it perfectly voices the complexity of the characters' feelings. L'Histoire du soldat invites the listener to a profound reflection which gives the hope of a balanced existence, where human values are present and constantly developed. By learning the lessons that this story teaches, man can be born again, becoming, with this second chance, wiser, more profound, more loving.

\section{Books}

\section{References}

1. Burde, Wolfgang - Stravinsky, Leben, Werke, Dokumente, Schott/Piper. Mainz und München, 1982

2. Craft, Robert - L'histoire du soldat. The Musical Revisions, the Scetches, the Evolution of the Libretto, in: The Musical Quaterly 66, 1980

3. Craft, Robert - Conversation with Igor Stravinky, London 1959

4. Craft, Robert - Igor Stravinsky - Memories and Commentaries, London 1960

5. Dömling, Wolfgang/Hirsbrunne, Theo - Über Stravinsky, Laaber Verlag

6. Hunkermöller, Jürgen - Igor Stravinkys Jazz - Portrait, Archiv für Musikwissenschaft, 1972

7. Lindlar, Heinrich - Lübes Stravinsky Lexikon, Lübbe Verlag: Bergisch Gladbach 1994

8. Lindlar, Heinrich - Igor Stravinsky, Lebenswege. Bühnenwerke, M\&T Verlag AG: Zürich/ St. Gallen1994

9. Ramuz, Charles, Ferdinand - Einnerungen an Igor Stravinsky, Frankfurt a. Main, 1974

10. Trapp, Michael - Studien zu Stravinskys L'histoire $d u$ soldat, BosseRegenburg, 1978 
11. Traub, Andreas - Igor Stravinsky L'histoire du soldat

\section{Scores}

1. Igor Stravinsky - Suite for violin, clarinet and piano, J\&W Chester, Ltd. London

2. Igor Stravinsky - L'histoire du soldat, J\&W Chester, Edition Wilhelm Hansen, London Ltd. 1924

\section{Discography}

1. Igor Stravinsky - L'histoire du soldat, Laurent Manzoni - Reciter, New Music Studium, Antonio Plotino - conductor, Arts - 47357 - 2

2. Igor Stravinsky - L'histoire du soldat - suite, Ensemble Incanto, Michaela Paetsch Neftel - violin, Ralph Manno - clarinet, Liese Klahn - piano, Arte Nova $74321-721052$

3. Igor Stravinsky - L'histoire du soldat Jean Cocteau - Reciter Peter Ustinov Devil Igor Markevitsch - Conductor Phillips - 420773 - 2

\section{Notes}

1. Stravinsky, I. An Autobiography. The Norton Library, 1962

2. Stravinsky, I., \& Craft, R. Expositions and Developments. Faber and Faber, 1962

3. https://www.latimes.com/archives/la-xpm-1990-09-30-ca-2098-

story.html\#: :text=\%E2\%80\%9CPulcinella'\%20was\%20my\%20discovery\%20of,i n\%20the\%20mirror\%2C\%20too.\%E2\%80\%9D 